\title{
Sexual Perversions: An Emerging Global Iceberg Phenomenon
}

\section{Sanjeev Davey*}

Professor, Department of Community Medicine, Muzaffar Nagar Medical College, India

*Corresponding Author: Sanjeev Davey, Professor, Department of Community

Medicine, Muzaffar Nagar Medical College, India.
Received: March 02, 2020

Published: March 20, 2020

(C) All rights are reserved by Sanjeev Davey.
Sexual Perversion is a type of human behavior that deviates from that which is understood to be orthodox or normal. The sexual behaviors that are considered in perversions are abnormal, repulsive or obsessive. derogatory and paraphilia forms [1,2]. Sexual perversion is an term which serve as a label for sexual activities considered outside the norm of heterosexual sexual desire and activity. This norm was defined as coitus with a person of the opposite sex with the aim of achieving orgasm through genital penetration [3].

Sexual perversion is a real controversial matter. It is often difficult to define because, it is not only a clinical phenomenon, but it is often seen as a social angle. Often Global society establishes what is perverse and what is not [4]. These days a varied sexual taste and needs in the form of oral sex (Penis and vaginal sucking), Anal Sex, 6 by 9 sex position, Lesbianism and Homosexuality are on rise due to easy availability of Porn from Internet as well as rise of civilized PROSTITUTION FROM INTERNET, WHERE easy available sex services in the form of Call Girls, Escorts in both developed and developing countries such as India are on rapid rise. This is emerging as a Global Iceberg disease Phenomenon as PORN CDs and Internet Sex Videos and Photos are easily available. Sexual fantasies in Masturbation are also a new entity in this area.

The iceberg phenomenon which describe a situation in which a large percentage of a problem is subclinical, unreported, or otherwise hidden from view can be applicable to Sexual Perversions. Thus, only the "tip of the iceberg" is apparent to the epidemiologist. This is what happening in our Global Society in context of Sexual Perversions.

Problematic sexual behavior through Smartphone's internet usage in the form of PORN WATCHING is increasingly found to have problematic sexual behaviors and it is rapidly evolving due to the easy and increasing accessibility of online sexual content and the immediate connectivity [5]. Study of Bennet EA (1933) reveals that there are many forms of Sexual Perversions such as (a) The emotional relationship between the pervert and others is an essential element in the condition. (b) The physical aspects of the perversion are of secondary importance to the mental. (c) The perversion indicates a failure in personal and social integration; and an effort is made to alter this by means of aggressiveness, adopted child-like conduct, and perversions [6].

The most common sexual paraphilias appearing in society are [7]: exhibitionism, or exposure of the genitals; fetishism, or the use of non-living objects, frotteurism, or touching and rubbing against a nonconsenting person, pedophilia, or the focus on prepubescent children, sexual masochism, or the receiving of humiliation or suffering.

The sexual slurs and cheap jokes doing rounds inside our home, male chauvinism, considering eve teasing as sort of sport, inappropriate touching in the public transport, Public Masturbation etc are appearing as new forms of acts of perverts [8]. One Study [9] reveals that Young men who have sex with men and who seek partners online also engage in other behaviors that place them at risk for HIV and other sexually transmitted infections.

So undoubtedly, the rise in pornography viewing is appearing directly proportional to the rise in the number of rape cases, sexual violence and the social degeneration' - as also rightly claimed by a noted gynecologist Dr. Shaibya Saldanha of Bangalore.

\section{Bibliography}

1. Martins Maria C and Ceccarelli Paulo. The So-called "Deviant" Sexualities: perversion or right to difference? Archived 2006-03-03 at the Way back Machine Presented in the 16th World Congress. "Sexuality and Human Development: From Discourse to Action". Havana, Cuba (2003).

2. Robin Skynner/John Cleese. Families and How to Survive them London (1994): 285.

3. https://www.encyclopedia.com/social-sciences/encyclopedias-almanacs-transcripts-and-maps/sexual-perversion 
4. Rossi R. "Diagnostic of sexual perversions". Journal of Endocrinology Investigation 26 (2003): 109-111.

5. Davey S and Davey A. "Assessment of Smartphone Addiction in Indian Adolescents: A Mixed Method Study by Systematic review and Meta analysis Approach". International Journal of Preventive Medicine 5 (2014): 1500-1511.

6. Bennet EA. "The Psychopathology of Sexual Perversions". Journal of the Royal Society of Medicine 6.8 (1933): 1030-1034.

7. Sexual Perversions

8. https://medium.com/indiamag/perversity-and-indian-menf6079f19fe42

9. Robert Garofalo., et al. "Tip of the Iceberg: Young Men Who Have Sex With Men, the Internet, and HIV Risk". American Journal of Public Health 97.6 (2007): 1113-1117.

\section{Assets from publication with us}

- Prompt Acknowledgement after receiving the article

- Thorough Double blinded peer review

- Rapid Publication

- Issue of Publication Certificate

- High visibility of your Published work Website: www.actascientific.com/

Submit Article: www.actascientific.com/submission.php Email us: editor@actascientific.com

Contact us: +919182824667 